\title{
The Relationship between Listening and Other Language Skills in International English Language Testing System
}

\author{
Hossein Bozorgian \\ Queensland University of Technology, Queensland, Australia \\ Email: h.bozorgian@qut.edu.au
}

\begin{abstract}
Listening comprehension is the primary channel of learning a language. Yet of the four dominant macro-skills (listening, speaking, reading and writing), it is often difficult and inaccessible for second and foreign language learners due to its implicit process. The secondary skill, speaking, proceeds listening cognitively. Aural/oral skills precede the graphic skills, such as reading and writing, as they form the circle of language learning process. However, despite the significant relationship with other language skills, listening comprehension is treated lightly in the applied linguistics research. Half of our daily conversation and three quarters of classroom interaction are virtually devoted to listening comprehension. To examine the relationship of listening skill with other language skills, the outcome of 1800 Iranian participants undertaking International English Language Testing System (IELTS) in Tehran indicates the close correlation between listening comprehension and the overall language proficiency.
\end{abstract}

Index Terms — listening comprehension, foreign language, second language, IELTS

\section{INTRODUCTION}

Whilst a substantial amount of research has been conducted in reading and writing skills, investigators (Hunsaker, 1990; Linebarger, 2001; Morris \& Leavey, 2006) have underscored the role of listening skill in human learning and development. Indeed, listening skill provides the primary impetus to initiate first, second and foreign language learning and later the medium of communication to sustain the long and often tedious learning process. Without adequate listening input, it is more likely for individuals not to accomplish long - term goals. The perception of the world and interpretation of experience occurs through listening (Linebarger, 2001). As individuals grow to school age, the dominance of this skill appears noticeable. Hunsaker (1990) found that more than three quarters of what children learn in school happens through listening in the classroom. Closely aligned with this, is the study conducted by Gilbert (2005), which demonstrated the prominence of listening in schools. The researcher found that $\mathrm{K}-12$ participants spend between $65 \%$ and $90 \%$ of their school time in learning, which is achieved, in fact, through listening trajectory. Thus, the current study looks into the relationship between listening comprehension widely in human learning and narrowly in IELTS performance. Here after, the significant relationship of listening with other language skills (speaking, reading and writing) is described. This paper begins with a broad discussion of background on listening research and then ends with the impact of listening in second and foreign language learning.

\section{BACKGROUND}

Research has found that improvement in listening skill has a positive effect on other language skills - reading, writing and speaking. To illustrate, Morris and Leavey (2006) conducted a study focusing on preschoolers' phonological development. The study reveals that listening instruction skills improve preschoolers' phonological awareness. Similarly, two other studies found out that the listening skills instruction assists middle school students to improve their reading comprehension (Badian, 1999; Bergman, 1999). In addition, the outcome of Bergman's (1999) study revealed that listening and reading stories at the same time lead participants to improve their reading comprehension performance. In addition to the impact of listening skill on reading comprehension, a study reported by Berninger (2000) shows that participants in Grades $1-6$ improve their spelling significantly through aural skill instruction whereas there is a high correlation between Grades $1-3$ and the improvement of narrative and expository composition in Grades 2 and 3 through listening instruction.

Given the prominence of listening comprehension in human learning, in general and with a particular focus on language learning, many investigators, such as Goh (2008), Feyten (1991), Pinell and Jaggar (2003), Janusk (2002), and Vandergrift (2007) demonstrate that listening skill is tested rather than taught in classrooms. A study conducted by Feyten (1991) focused on three enquiries (i) whether listening skill is worth paying more attention in foreign language learning (ii) or improving listening skill leads to higher achievements in language learning and (iii) if there is a relationship exists between listening ability and oral proficiency skills. The results showed that the relationship between 
the overall listening ability and effective foreign language acquisition is statistically significant. Particularly, a statistically significant relationship exists between listening ability and overall foreign language proficiency; between listening ability and foreign language listening comprehension skills; and between listening ability and foreign language oral proficiency skills. Listening is at the heart of language learning, but it is the least understood and least researched skill in language learning and is often disregarded by foreign and second language instructors (Brown, 2008). As Oxford (1993) appropriately notes, "in many instances listening is treated like a neglected stepchild" (p. 205).The studies presented above shows multiple significances of listening skill in learning in general with a particular focus on second and foreign language learning. Now that listening is crucial for human learning, it is worthwhile to seek the root of this fundamental skill.

\section{A. Research on the Root of Listening Skill}

The significance of listening skill in effective communication has been recognized for a century. Rankin (1926) conducted a study and found that listening skill was the most dominant skill for the mode of human communication. However, there were no more similar studies until the 1940s. The base of listening inquiry was primarily laid academically in the late 1940s and the founders (James Brown, Ralph Nichols and Carl Weaver) of the listening skill were considered as the "fathers of listening" (Vocile, 1987). Listening skill was taken into the second and foreign language research field in the mid $20^{\text {th }}$ Century and many researchers put listening as the focus of their studies. After half a century, a professional committee International Listening Association (ILA) was established in 1979 to develop listening skill (Feyten, 1991). Knowing how to entail listening instruction and assessment in the school syllabi was the main target of the pedagogy. Steven (1987) pointed out that many studies provide a focus on either understanding listening comprehension or listening critically - agree or disagree with oral input.

Similarly, Floyed (1985) defines listening as a process entailing hearing, attending to, understanding, evaluating and responding to spoken messages. He further believes that listeners should be active participants in communication process. The nature/purpose of listening skills varies as the context of communication differs. Wolvin and Coakley (1988) propose five different kinds of listening. First, discriminative listening helps listeners draw a distinction between facts and opinions. Second, comprehensive listening facilitates understanding oral input. Third, critical listening allows listeners to analyse the incoming message before accepting and rejecting it. Fourth, therapeutic listening serves as a sounding board and lack any critiques, e.g., advising. Finally, appreciative listening contributes listeners to enjoy and receives emotional impressions. All the varieties of listening help to demonstrate that listening is an active process rather than a passive product. The authors define the process of listening as making sense of oral input by attending to the message. Thus, this study adopts the second definition of listening - understand the oral input mentioned by Wolvin and Coakley as a tool to evaluate the research assumption. The current study seeks to delve into the correlation between listening and other skills in International English Language Testing System.

\section{B. The Relationship between Listening and Second/Foreign Language Proficiency}

Language development involves four fundamental and interactive abilities: listening, speaking, reading and writing. The attempt has widely been made to teach four macro skills in second and foreign language for more than 60 years. Berninger and Winn (2006) emphasize that external and internal environment interacts with functional systems to extent, which the nature-nurture interaction at birth evolves over the course of time. The question is how much and how long the basic skill of listening gains attention in second and foreign language learning while listening is recognized to play a significant role in primary and secondary language acquisition (Ellis, 1994; Faerch \& Kasper, 1986). In the 1970s, Communicative Language Teaching (CLT) method was introduced to develop language learning proficiency. Some prominent researchers (Asher, 1977; Krashen, 1992) highlighted the significance of listening in the pedagogy. Krashen (1992) has argued that language acquisition highly depends on the decoding process of making sense of incoming messages. Language acquisition never occurs without access to the comprehensible language input (Rost, 1994) because in addition to visual learning, more than three quarters (80\%) of human learning occurs through listening direction (Hunsaker, 1990). Returning to language acquisition, Nunan (2003) suggested that listening is the gasoline that fuels the acquisition process. Thus, the main reason experts emphasize the significance of listening in language acquisition is the frequency of listening in language development. However, much of the relevant research incorporated into listening as an inevitable medium to drive primary and secondary language acquisition. What is more, none of them focuses on the relationship between listening skill and other language skills - speaking, reading and writing in English as a Foreign Language (EFL). The current research study aims to fill this gap by providing empirical data obtained in a large-scale investigation of 1800 participants taking the international known language proficiency test - IELTS administered in the capital of Iran, Tehran. Followed are discussions about each single language skill associating with listening skill.

Much debate continued to prove the increasing influence of listening skill on the other three language skills speaking, reading and writing. To illustrate, Rost (1994) proposed three reasons showing the essential role listening plays to improve speaking skill. First, spoken language provides a means of interaction for the learner. Because learners must interact to achieve understanding, access to speakers of the language is essential. Moreover, learners' failure to understand the language they hear is an impetus, not an obstacle, to interaction and learning. Second, authentic spoken language presents a challenge for the learner to attempt to understand the language as native speakers actually use it. 
Third, listening exercises provide teachers with the means for drawing learners' attention to new forms (vocabulary, grammar, new interaction patterns) in the language. Listening and reading have much in common in terms of input processing. Pearson and Fielding (1991) linked listening with reading skill. They argued that like reading, listening involves phonological, syntactic and semantic orchestration of skill and the knowledge controlled by cognitive processes at the same time. Further, Very recently, a study conducted by Yalcinkaya, Muluk and Ashin (2009) shows that the foundation of receptive (reading) and expressive (writing) skills is built upon aural (speaking) and oral (listening) skills. They argue that written language skills hardly develop without realizing the infrastructure of a language - the sounds. They conclude that listening ability strongly influences speaking, reading and writing ability. Now that classroom based research indicates the significance of listening in English as a foreign language learning, the following section discusses the IELTS research and specifically the relationship between listening and other language skills.

\section{IELTS Research Reports}

A study conducted by Coleman and Heap (1998) addressed the areas of perceived confusion or misunderstanding that candidates sometimes have when attempting to comprehend the rubrics of the IELTS Academic Reading and Listening sub-test. The findings demonstrated that few participants misjudged the requirements of the rubrics. It was often the wording and style of the questions themselves that caused the greatest difficulty, and IELTS must be applauded for the reasonably low level of misunderstandings generated by the rubrics. Another study investigated by Weir, Hawkey, Green, Unaldi, and Devi (2009a) focused on the relationship between the academic reading construct as measured by IELTS and the reading experiences of participants in the first year of study at a British university. The participants' contextual parameters of the reading text were compared with those performance conditions obtained for reading activities in the IELTS test. The finding indicated that any reading problems might decrease the higher the reading band score gained in IELTS tests before the entry is investigated. In terms of the cognitive load process in reading comprehension, Weir et al. (2009b) explored the cognitive process underlying the academic reading construct as measured by IELTS. The researchers used UK university students' retrospection to specify students' use of cognitive processes when performing various tasks in an IELTS reading test. The finding showed that there is a close association between the construct measured by IELTS and that of academic reading in the target space.

An IELTS listening test has four components, such as daily conversation, public speech, academic discussion and academic lecture. Field (2009) has investigated the cognitive validity of the lecture-based question in the IELTS listening paper. He has compared the performance and experience of students when completing a sample IELTS task with their performance and experience when doing similar task that is not limited by test administration situation. The finding shows that no clear correlation was found between individual performance under test condition and freer 'lecture' condition. First and foreign language speakers might use similar strategies to approach listening tasks. Badger and Yan (2009) conducted a study investigated the use of tactics and strategies by Chinese students in the listening component of IELTS test. 24 Chinese native speakers with an IELTS level for the listening paper of between 5.5 and 6.5, and 8 native/expert users of English took a sample of listening test. The finding using a think aloud protocol and an independent samples 2-tailed t-test provides a grounded insight into lack of significant differences between the two groups in terms of strategy use.

This review of the research argues that limited evidence has been found in addressing the relationship between listening skill and other language skills. The review also demonstrates that there are inadequate investigations focusing on the contributions of listening skill bestowing to other language skills. Afterward, having created these composite IELTS' discrete and overall performance, I followed a correlation design to measure the relationship between listening and other language skills - speaking, reading and writing.

\section{RESEARCH QUESTION}

In light of the above discussions on the significance of listening skill in language learning, in general and second and foreign language, in particular, the limitation still exists on acknowledging listening skill in English as Foreign Language (EFL) learning in Iran. Thus, the purpose of the current study is to examine the relationship between listening and speaking, reading and writing performance in IELTS. In particular, the proposed research addressed the following question:

- Does listening skill have a close relationship with other language skills, such as speaking, reading and writing?

\section{A. The Purpose of the Proposed Study}

This paper brings the attention to rarefied and critical skill in language learning, namely listening with a particular focus on EFL learning in Iran. There is some initial evidence demonstrating the development of listening skill, which leads to the efficiency of second and foreign language development. However, more research is needed on examining the significance of listening skill in improving other skills, such as speaking, reading and writing in second and foreign language learning, which indeed assists language instructors in drawing particular attention to this basic skill in the classroom. In what follows, I ask the proceeding question: What is the relationship like between listening skill proficiency and that of speaking, reading, and writing proficiency skills in EFL through IELTS assessment? 


\section{B. Method}

All of the participants were Iranian and spoke Persian as their first language. To test the research assumptions, all the participants undertook the academic training International English Language Testing System (IELTS).

\section{Participants and Context}

The participants in the study were $701^{1}$ English for Speakers of Other Language (ESOL) participants, with an age range of $24-37$ in the capital of Iran, Tehran, who were planning for either continuing their college education or beginning their professional careers in an English speaking country in summer 2010. The participants IELTS performance in detail were downloaded from www.ieltstehran.com. In Iran, at school level, listening skills are not taught due to the predominant use of the traditional Grammar Translation Method (GTM) which focuses only on reading and writing skills. At university level, depending on the field of study, reading skills are mainly taught for 3-5 hours per week for each term. Listening skills are taught only in language institutes which have a Communicative Language Teaching (CLT) approach. Often, despite instruction of listening skill being specified in the syllabus of many English language institutes, teachers do not teach listening skills but test it in the EFL classrooms in Iran. Currently, listening skill is taught through vocabulary introduction in pre-listening to the students and they examine correct responses in post-listening comprehension questions. The process of explicitly teaching listening skill is overlooked, but the product of listening skill is measured through exams involving multiple-choice or true/false comprehension questions, which are a regular feature of classroom practice.

\section{Instrument}

IELTS was the only research instrument used to examine the relationship between listening skill and other language skills - speaking, reading and writing in EFL.

\section{E. IELTS}

IELTS provides a profile of a candidate's ability to use English language. Candidates received scores on a Band from 1 (Non User) to 9 (Expert User). Candidates received a score for each test component - Listening, Reading, Writing and Speaking. Candidates receive a score for each test component - Listening, Reading, Writing and Speaking. The individual scores are then averaged and rounded to produce an overall Band Score. IELTS is available in two formats Academic and General Training. All candidates took the same Listening and Speaking modules but different Reading and Writing modules. The Academic version is for tertiary study for those who want to study or train in an English Speaking University or tertiary institution. Admission for undergraduate and postgraduate courses is based on the results of the academic test scores. The General training format - for school, work or migration focuses on basic survival skills in a broad social and educational context. It is for those who are going to English speaking countries to do secondary education, work experience or training programs. People migrating to Australia, Canada, and New Zealand must sit the General Training test (http://www.ielts.org/institutions/test_format_and_results.aspx).

The validity and reliability of the international known test is determined conclusively due to the high demand of this test. In other words, a passing result in this test is indeed a door opening to all international students to be a college student in an English speaking country. Linked to this idea, over 1,000,000 people a year are now using IELTS to initiate a new life in a foreign English-speaking country. Over 6,000 educational institutions, government agencies and professional organisations across 120 countries around the world - including over 2,000 institutions in the USA recognize IELTS band scores for a range of purposes including further duration, training and immigration (http://www.ieltstehran.com/index.php).

\section{Data Analysis}

Calculating simple correlations examining the relations between listening as a basic skill and speaking, reading and writing, the current study used SPSS 18 for windows for the statistical analysis. The aim of correlation analysis in this proposed study is that examining participants IELTS performance in Iran confirms the research hypothesis, which is a relation exists between listening and other language skill e.g., speaking, reading, and writing. As part of descriptive data analysis, an ANOVA, Post hoc Comparisons, a Pairwise Correlation Coefficient and a Scatter plot were used to measure the relationship between listening skill performance and other language skills performance - speaking, reading and writing as well as the overall performance.

\section{RESULTS}

A summary of the IELTS performance analysis is presented in this section. The Table 2 displays the descriptive statistics for each language skill. The lowest attainment is for speaking with a mean of (5.568) and standard deviation (.889). In contrast, reading with the mean (6.987), and standard deviation (.789) shows the highest achievement. As indicated on Table 2, listening entailing the mean (5.724), standard deviation (.069) places one before the last skill -

\footnotetext{
${ }^{1}$ There were actually 1854 participants, but 54 discrete and overall IELTS scores were deleted due to their extreme scores.
} 
writing score with the mean (6.564) and standard deviation (.029). In brief, participants scored lower on aural/oral skills than orthographic skills in IELTS.

TABLE 1.

DESCRIPTIVE ANALYSIS OF ALL LANGUAGE SKILLS

\begin{tabular}{lllllll}
\hline & N & MEAN & STD. DEVIATION & STD. ERROR & MINIMUM & MAXIMUM \\
\hline LISTENING & 1800 & 5.724 & .069 & .038 & 1.00 & 9.00 \\
SPEAKING & 1800 & 5.568 & .889 & .035 & 1.00 & 9.00 \\
READING & 1800 & 6.987 & .789 & .029 & 3.40 & 9.00 \\
WRITING & 1800 & 6.564 & .826 & .029 & 1.50 & 9.00 \\
\hline
\end{tabular}

A one-way between - group analysis of variance (see table 2) was conducted to explore the relationship between listening and speaking, reading and writing skills. IELTS' scores are divided into three groups according to different language skills (listening and speaking, listening and reading and listening and writing). There is a statically significant difference at the $\mathrm{p} \leq .05$ level in performance within three groups: $\mathrm{F}(7200)=703.756, \mathrm{p}=.000$.

\begin{tabular}{llllll}
\multicolumn{5}{c}{ TABLE. 2 } \\
ANOVA & Sig. \\
\hline \hline & Sum of Squares & df & Mean Square & F & .000 \\
\hline Between Groups & 1981.672 & 3 & 856.454 & 703.756 & \\
Within Groups & 7200.352 & 1800 & .857 & & \\
Total & 9182.024 & 1800 & & & \\
\hline
\end{tabular}

The post - hoc comparisons using the Tukey HSD test in Table 3 indicates that the mean score for the three groups (see also, Table, 1) - Listening ( $\mathrm{M}=5.724, \mathrm{SD}=.069)$ was significantly different from Speaking $(\mathrm{M}=5.568, \mathrm{SD}$ $=.889)$, Reading $(\mathrm{M}=6.987, \mathrm{SD}=.789)$ and Writing $(\mathrm{M}=6.564, \mathrm{SD}=.826)$.

TABLE 3.

POST HOC COMPARISONS FOR DISCRETE LANGUAGE SKILLS TUKEY HSD TEST

\begin{tabular}{lllllll}
\hline \hline $\begin{array}{l}\text { Categories } \\
(\mathbf{I})\end{array}$ & $\begin{array}{l}\text { Categories } \\
(\mathbf{J})\end{array}$ & $\begin{array}{l}\text { Mean Difference } \\
(\mathbf{I}-J)\end{array}$ & Std. Error & \multicolumn{2}{c}{ Sig. } & \multicolumn{2}{c}{ 95\% Confidence Interval } \\
\cline { 5 - 6 } Listening & Speaking & $.176454^{*}$ & & & Lower Bound & Upper Bound \\
& Reading & $-1.1745^{*}$ & .03564 & .003 & .0367 & .2872 \\
& Writing & $-.63456^{*}$ & .03874 & .000 & -1.3452 & -1.0234 \\
& & .04123 & .000 & -.7342 & -.4791 \\
\hline
\end{tabular}

$*$ The mean difference is significant at the 0.05 level.

However, the relationship between listening and other language skills is closely intertwined. As Table 4 indicates, the relationship between listening performance and speaking, reading and writing skill performance was investigated using Pairwise correlation coefficient in Table 5. Preliminary analyses were performed to en sure the violation of assumptions. There was a strong, positive correlation between the variables, listening and speaking $(r=.654, \mathrm{n}=1800, \mathrm{p} \leq .000)$, reading $(\mathrm{r}=.735, \mathrm{n}=1800, \mathrm{p} \leq .000)$ and writing $(\mathrm{r}=.643, \mathrm{n}=1800, \mathrm{p} \leq .000)$. The correlation between listening and the overall IELTS performance $(\mathrm{r}=.887, \mathrm{n}=1800, \mathrm{p} \leq .000)$ is even stronger.

TABLE 4

PAIRWISE CORRELATION COEFFICIENT

\begin{tabular}{|c|c|c|c|c|c|c|}
\hline \multirow{4}{*}{ Listening } & & Listening & Reading & Writing & Speaking & Overall \\
\hline & Pearson Correlation & 1 & $.735^{* *}$ & $.643^{* *}$ & $.654^{* *}$ & $.887^{* *}$ \\
\hline & Sig. (2-tailed) & & .000 & .000 & .000 & .000 \\
\hline & $\mathrm{N}$ & 1800 & 1800 & 1800 & 1800 & 1800 \\
\hline
\end{tabular}

\section{DISCUSSION}

Listening is the basic bricks and mortar of a language acquisition. Within my research paradigm, I expected the listening performance in IELTS to have the stronger association with the second language proficiency in overall performance. Based on the results of the study, the correlation coefficients confirmed this prediction. The correlation between audio skill with other language systems - speaking, reading and writing as well as overall IELTS performance is significant. Despite a close relationship between aural/oral skills in nature, the correlation between listening and reading, however, was stronger than listening and speaking skill performance. Writing is the last skill learned by first and second language learners. However, the correlation between listening and writing performance is very close to that of the correlation between listening and speaking. Thus, reading, due to its common comprehension features with listening had the highest correlation score in IELTS. The high correlation of reading with listening is aligned with the 
cognitive load process in reading comprehension which Weir et al. (2009b) found that there is a high correlation between the construct measured by IELTS and that of academic reading in the target space.

Given that I found many studies (Ellis, 1994; Nunan, 2003; Richards, 2005) showing the multiple influences of listening in primary and secondary language learning, the outcome of this study points out that listening performance have a large correlation with EFL proficiency. Emphasizing the relationship between listening and writing skill - one starts acquiring listening at birth but writing acquisition starts at school age in first language, the EFL test result confirms the core of Shanahan's (2006) discussion about the impact of listening skill instruction on writing development. The multiple correlations in the current study focused on one dependent variable - listening and three independent variables - speaking, reading and writing as well as overall performance accounting for interrelationship of the independent variables. The analysis produced multiple coefficient of $0.887(\mathrm{p} \leq .000)$. This result is remarkably high to consider the importance of listening skill in EFL classrooms. In the end, the finding - the higher the listening score, the better the speaking also supports James (1985) and Rost's (1994) research suggesting three essential roles listening plays to improve speaking skill. Rost maintained that spoken language provides a means of interaction for the learner. This is because learners must interact to achieve understanding, and access to speakers of the language is essential.

Returning to a high correlation between listening and reading, Dörnyei (2001) maintained that focusing on the situation contributes significantly to the motivation of a particular task. This opinion aligns with participants in this study who benefit from reading skill in English at middle, high schools and college as a subject. The finding of this study supports the fact that the situational environment is an important element influencing language learning. This could not be seen as a surprising result showing that participants, due to devoid of English language exposure in Iran, participants score aural/oral skill less than orthographic and expressive skills in this study. Similarly, the result of this study confirms Hulstijn (2001) argument in psycholinguistic perspectives in that having access to basic knowledge of vocabulary stored in long - term memory contributes learners to the systematic rehearsal and other cognitive strategies. Further, the finding of this study demonstrating the close relationship between listening and reading performance is consistent with the results of Badian (1999) and Bergman's (1999) research. Thus, participants' background knowledge of reading assisted them to score the highest in the reading band.

\section{CONCLUSION AND Future RESEARCH DiRECTION}

This study examined the relationship between listening and other EFL skills - speaking, reading and writing as well as overall performance in the International English Language Testing System. The data collected for the purpose of this study were the results announced on the IELTS centre site in Iran. The significant positive correlations I found between listening and other language skills are particularly strong within the context of EFL providing evidence that listening skill matters even in situation where English is not the primary language. This finding is important because there are few studies reporting the significant correlation between listening skill and EFL language proficiency. Closely aligned with the finding, there is a very strong body of support for syllabus designers and English language instructors to frame the domain of listening skill attention in the classroom instruction. Even though this study provided a focus on EFL listening relationship with other language skills without examining the impact of EFL listening skill instruction, the results are strong enough to guarantee further research looking at the impact of learning strategy on EFL language proficiency.

\section{REFERENCES}

[1] Asher, J. J. (1977). Learning another language through actions: The complete teacher's guidebook. Los Gatos, CA: Sky Oaks.

[2] Badger, R., \& Yan, X. (2009). The use of tactics and strategies by Chinese students in the listening component of IELTS. IELTS Research Reports SiLT 4, 67-95.

[3] Badian, N. A. (1999). Reading disability defined as a discrepancy between listening and reading comprehension. Journal of Learning Disabilities, 32, 138-148.

[4] Bergman, O. (1999). Wait for me! Reader control of narration rate in talking books. International Reading Association's Reading Online. Retrieved February 2, 2009, from www.readingordine.arg larticles lart _index.asp?HREF=bergman/index.html

[5] Berninger, V. (2000). Development of language by hand and its connections to language by ear, mouth and eye. Topics in Language Disorders, 20, 65-84.

[6] Brown, G. (2008). Selective listening. System: An International Journal of Educational Technology and Applied Linguistics 36(1), 10-21.

[7] Dörnyei, Z. (2001). Motivational strategies in the language classroom. Cambridge: Cambridge University Press.

[8] Colman, G., \& Heap, S. (1998). The misinterpretation of directions for the questions in the American reading and listening Sub-Test of the IELTS test. IELTS Research Reports SiLT, 4, 38-71.

[9] Ellis, R. (1994). The study of second language acquisition. Oxford: Oxford University Press.

[10] Faerch, C., \& Kasper, G. (1986). The role of comprehension in second language learning. Applied Linguistics, 7, $257-274$.

[11] Feyten, C. M. (1991). The power of listening ability: An overlooked dimension in language acquisition. The Modern Language Journal, 75(2), 173-180.

[12] Field, J. (2009). The cognitive validity of the lecture-based question in the IELTS listening paper. IELTS Research Reports, 9, $17-65$. 
[13] Floyed, J. (1985). Listening a practical approach. Glenview, Illinois: Scott Foreswan and Company.

[14] Gilbert, M. B. (2005). An examination of listening effectiveness of educators: Performance and preference. Professional Educator, 27(1/2), 1-16. Retrieved January 30, 2008, fromsearch.ebscohost.com/login.aspx? direct $=$ true $\& \mathrm{db}=\mathrm{aph} \& \mathrm{AN}=17334894 \&$ site $=$ ehost-live

[15] Goh, C. (2008). Metacognitive Instruction for Second Language Listening Development: Theory, Practice and Research Implications. RELC Journal: A journal of language teaching and research in Southeast Asia, 39(2), 188-213.

[16] Hulstijn, J. H. (2001). Intentional and incidental second language vocabulary learning: A reappraisal of elaboration, rehearsal and automaticity. In P. Robinson (ed.), Cognition and second language instruction. Cambridge: Cambridge University Press, $258-286$.

[17] Hunsaker, R. A. (1990). Understanding and developing the skills of oral communication: Speaking end listening (2nd ed.). Englewood, CO: J. Morton Press.

[18] James, C. J. (1985). The testing of proficiency in listening comprehension: Guiding for teaching in a meeting the call for excellence in the foreign language classroom. Selected papers from the Central States Conference on the Teaching of Foreign Languages.

[19] Janusk, L. (2002). Teaching listening: What do we do? What should we do? International Journal of Listening, 16, 5-35.

[20] Krashen, S. (1982). Principles and Practice in Second Language Acquisi- tion. New York: Pergamon,

[21] Linebarger, D. L. (2001). Beginning literacy with language: Young children learning at home and school. Topics in Early Childhood Special Education, 21, 188-192.

[22] Morris, T., \& Leavey, G. (2006). Promoting phonological awareness in nursery-aged children through a Sure Start Early Listening programme. International Journal of Early Years Education, 14(2), 155-168.

[23] Nunan, D. (2003). Listening in a Second Language. The Language Teacher, Retrieved February 2, 2010, from http://www.jaltpublications.org/old_tlt/articles/2003/07/nunan

[24] Oxford, R. L. (1993). Research Update on Teaching L2 Listening. System, 21(2), 205-211.

[25] Pearson, P. D., \& Fielding, L. (1991). comprehension instruction. In R. Bar, et al (eds.) Handbook of Reading Research. vols. 2815-860. New York: Longman.

[26] Pinell, G. S., \& Jaggar, A. M. (2003). Oral language: Speaking and listening in elementary classes. In J. Flood, J. M. Jansen, D. Lapp, \& J. R. Squire (ads.), Handbook of Research on Teaching the English Language Arts, 691-720. Mahwah, NJ: Lawrence Erlbaum Associates.

[27] Rankin, T. P. (1926). The measurement of the ability to understand spoken language. Unpublished Ph. D. dissertation, University of Michigan. Language Journal, 78, 199-221.

[28] Richards, J. C. (2005). Second Thoughts on Teaching Listening. Regional Language Centre Journal, 36(1), 85-92.

[29] Rost, M. (1994). Introducing listening. London: Penguin Group.

[30] Semel, E., Wiig, E. H., and Secord, W. A. (2003). Clinical evaluation of language fundamentals: Fourh Eds.San Antonia, TX: Psychological Corporation.

[31] Shanahan, T. (2006). Relations among oral language, reading and writing development. In MacArthur, A. C., Graham, S., \& Fitzgerald, J. Handbook of writing research. The Guidford Press.

[32] Steven, R. (1987). A study of effective and ineffective listening dyads using the systems, theory, and principle of Entropy. Journal of the International Listening Association 1, 32-53.

[33] Vandergrift, L. (2007). Recent development in second and foreign language listening comprehension research. Language Teaching, 40, 191-210.

[34] Voncile, S. (1987). A beginning, and an editor anticipates. Journal of the International Listening Association, 1, 1-2.

[35] Weir, C., Hawkey, R., Green, A., Unaldi, A., \& Devi, S. (2009a). The cognitive processes underlying the academic reading construct as measured by IELTS. IELTS Research Reports, 9: 157-189.

[36] Weir, C., Hawkey, R., Green, A., Unaldi, A., \& Devi, S. (2009b). The relationship between the academic reading construct as measured by IELTS and the reading experiences of students in their first year of study at a British university. IELTS Research Reports, 9, 97-156.

[37] Wolvin, A., \& Coskley, C. (1988). Listening. Du- buque, IA: Brown.

[38] Yalcinkaya, F., Muluk, N. B., \& Ashin, S. (2009). Effects of listening ability on speaking, writing and reading skills of children who were suspected of auditory processing difficulty. International Journal of Pediatric Otorhinolaryngology, 73(8), 11371142 .

Hossein Bozorgian is a PhD candidate in Queensland University of Technology in Queensland, Australia, and has presented several national and international conferences in the field. He is currently working on metacognitive instruction and using strategies to promote second and foreign language listening comprehension. 